\title{
STRATEGICKÉ PLÁNOVÁNÍ VZDĚLÁVACÍ ČINNOSTI MUZEA $^{1}$

\section{MONIKA MAŽÁROVÁ}

\section{ABSTRAKT/ABSTRACT}

Strategické plánování tvoří nepostradatelnou součást marketingu $\mathrm{v}$ ziskovém sektoru a v době sílící konkurence a proměnách ve způsobu trávení volného času se stává přínosným také $\mathrm{v}$ muzeích. Text se tak v obecné rovině zabývá teorií strategického plánování a jeho aplikací do specifického prostředí českých muzeí $\mathrm{s}$ užším zaměřením na vzdělávací činnost. Zhodnotí význam strategického plánování v muzejních institucích, vymezí pojem vzdělávací strategie, popíše fáze tohoto procesu a navrhne ošetření pro případná rizika úspěšné implementace vzdělávací strategie.

\section{Strategic planning of museum education activities}

Strategic planning forms an integral part of marketing activities within the profitable sector, and at the time of growing competition and changes in the way of spending free time it also becomes beneficial to museums. The text is thus dealing at a general level with the theory of strategic planning and its implementation into the specific milieu of Czech museums focused narrowly on educational activity. It will evaluate the significance of strategic planning in museums, define the term educational strategy, describe the phases of this process, and propose treatment of possible risks of a successful implementation of the educational strategy.

1 Tento text vychází z diplomové magisterské práce autorky: MAŽÁROVÁ, Monika. Vzdělávací strategie Jihomoravského muzea ve Znojmě. Brno: Masarykova univerzita, Filozofická fakulta, Ústav archeologie a muzeologie, 2015. Diplomová práce. Vedoucí práce Mgr. Lenka Mrázová.

\section{KLÍČOVÁ SLOVA/ KEYWORDS}

muzeum - muzejní edukace - strategické plánování - vzdělávací politi-

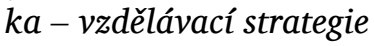
museum - museum education - strategic planning - education policy educational strategy

Muzejní edukace vždy tvořila zejména skrze výstavy a expozice nedílnou součást muzejní práce. $\mathrm{V}$ posledních dvou desetiletích zažila nebývale velký nárůst zaměřením na dětského návštěvníka (jak $\mathrm{v}$ rámci školních skupin, tak rodin s dětmi). A v právě rychle se vyvíjejícím prostředí muzejněpedagogické praxe lze uplatnit strategické plánování se všemi jeho přínosy.

\section{Strategický marketing a s ním} i strategické plánování proniká do muzejního prostředí ze ziskového sektoru, kde pomáhá zefektivnit chod samotné firmy a zvýšit její konkurenceschopnost a tržby. Muzea mají sice charakter neziskové instituce, nicméně zaměření současné společnosti na výkon a neustálé poměřování nutí hledat muzea způsoby, jak docílit vyšší kvality poskytovaných služeb - a tím i návštěvnosti, která je dnes jedním z hlavních hodnotících kritérií jejich činnosti. A jedním z možných nástrojů podporujících zvýšení kvality služeb a zájmu veřejnosti je strategický plán, tj. formální dokument stanovující časově vymezený záměr činností $\mathrm{k}$ dosažení definovaných cílů a umožňující další rozvoj organizace, případně minimalizující negativní dopady změn vnějšího prostředí.
Proč ale vůbec vzdělávací činnost strategicky plánovat? Co se skrývá za strategickým plánováním vzdělávací činnosti muzea? Jak vypracovat strategický plán a úspěšně jej převést do praxe? Právě tyto otázky zodpoví následující text.

\section{Proč strategicky plánovat vzdělá-} vací činnost muzea?

Již před téměř dvaceti lety poznamenal Jiří Bárta, že podmínky existence kulturních institucí primárně nevýdělečného charakteru (tedy i muzeí) se začínají rovnat způsobu fungování soukromého sektoru zaměřeného na zisk, a musí tak prokazovat svoji konkurenceschopnost. ${ }^{2}$ Zatímco dříve muzejním institucím obvykle stačila povaha jejich činnosti a obecný status významnosti, dnes podléhají hodnocení na základě šíře dosahu vlastních aktivit (tj. počtů návštěvníků, celospolečenský přínos atp.). Tuto proměnu podpořila rovněž změna ve způsobu trávení volného času a rozvoj tzv. volnočasového průmyslu. ${ }^{3}$ Muzea, stejně jako další kulturní instituce, tvoří soubor produktů ucházejících se o své „spotřebitele“ pouze $\mathrm{v}$ určitém místě, na něž jsou muzea pevně vázána a jako statické objekty musí najít způsob, jak v dnešním dynamickém světě opakovaně získat návštěvníky. ${ }^{4}$

Právě strategický marketing se stal $\mathrm{v}$ době velkých změn vhodným nástrojem pro revizi dosavadní činnosti, úpravu směřování organizace

\footnotetext{
2 BÁRTA, Jiří. Strategické pánování pro nezisko vé organizace. Praha: Nadace rozvoje občanské společnosti, 1997, s. 14.

3 KESNER, Ladislav. Marketing a management muzeí a památek. Praha: Grada, 2005, s. 12-13.

4 JOHNOVÁ, Radka. Marketing kulturního dědic tví a umění. Art marketing $v$ praxi. Praha: Grada, 2008, s. 272.
} 
a následné vytyčení cílů. $\mathrm{V}$ případě muzejních institucí je však nutné chápat marketing jen jako pomocníka ve zprostředkování kulturního dědictví veřejnosti, jako nástroj pomáhající k dosažení vytyčených strategických cílů. ${ }^{5}$

Strategický marketing a plánování pomáhají udržet zájem o edukační činnost muzea, rychleji a jistěji navrátit investice, zajistit větší efektivnost a produktivitu, ale i lepší zpětnou vazbu nebo podpořit týmovou práci. ${ }^{6}$ Strategické plánování dále v ideálním případě přispívá ke shodě mezi organizací a zřizovatelem, stejně jako mezi jednotlivými zaměstnanci $v$ jejím směřování, prioritách a plánech. Umožňuje všem zainteresovaným posoudit, co bylo dosud v rámci vzdělávací činnosti muzea vykonáno, jaké jsou možnosti organizace ve svém rozvoji a jakých výsledků má společnými silami muzeum dosáhnout. V neposlední řadě také umožňuje změnit přístup organizace na proaktivní, nebot napomáhá předvídat různé události a obrátit je ve svůj prospěch.

Dle Eilean Hooper-Greenhill strategické plánování umožňuje také zvyšovat reputaci organizace, pracovní uspokojení, kvalitu služeb, oslovení širšího spektra návštěvníků, šetřit čas díky stanoveným prioritám, přesné zacílení služeb, získat podporu dalších institucí. ${ }^{7}$ Dále významnost strategického plánování (nejen) pro muzea shrnují autoři publikace Museum Marketing and Strategy do pěti výhod: „kontrola a rozvoj činnosti muzea, poskytnutí rámce pro rozhodovací proces, vytvoření základu pro plánování nových iniciativ, rozpoznání způsobů motivace zaměst-

\footnotetext{
5 JOHNOVÁ, Radka. Marketing kulturního dědic tví a umění. Art marketing v praxi. Praha: Grada, 2008, s. 268.

6 JAKUBÍKOVÁ, Dagmar. Strategický marketing. Strategie a trendy. Praha: Grada, 2013, s. 18.

7 HOOPER-GREENHILL, Eilean (ed.). Writing a Museum Education Policy. Leicester: University of Leicester, Department of Museum Studies, 1991, s. 7.
}

nanců, evidování a reflektování změn vnějščho prostředí a jeho vlivu na organizaci."8

Význam strategického plánování spočívá nejen v pomáhání koordinace jednotlivých činností pracovníků tak, aby společně směřovaly $\mathrm{k}$ naplnění vytyčených cílů, ale jeho prostřednictvím se také organizace a její vzdělávací činnost prezentuje veřejnosti jednotným dojmem. Stěžejní hodnota vypracovaných strategií pak leží př̀edevším v objevování nových možností pro rozvoj edukační činnosti skrze analýzy a v napomáhání jejímu růstu stanovenými záměry. Dvojice autorů Tomáš Kažmierski a Petr Pelcl ve své praktické příručce doporučují neziskové organizaci strategické plánování, protože povede „k její dlouhodobé udržitelnosti a zlepšování kvality jejího vnitřního fungování nebo zvyšování kvality poskytovaných služeb a realizovaných projektü “ a rozdělí „složitou realitu života do realizovatelných kroků $v$ rámci vnitřně provázané struktury."9

Po dobu vymezeného plánovacího období vzdělávací strategie pomáhá tento dokument usnadnit nejen každodenní činnost pracovníků zaměřených na muzejní edukaci (např́íklad stanovená programová nabídka, struktura a forma edukačních programů, soupis plánovaných potřebných didaktických pomůcek a substitutů pro žádost o dotace atp.), ale zároveň celému muzeu, zřizovateli a poskytovatelům dotací a grantů uvědomit si významnost vzdělávací činnosti muzea.

Rozhodne-li se muzeum (at už vedení, či jen odpovědný pracovník)

\footnotetext{
8 KOTLER, Neil G., Philip KOTLER a Wendy I. KOTLER. Museum Marketing and Strategy. De signing Missions, Building Audiences, Generating Revenue and Resources. San Francisco: Jossey-Bass, 2008, s. 43-44.

9 KAŽMIERSKI, Tomáš a Petr PELCL. Projektové a strategické plánování pro neziskové organizace. Praha: Regionální environmentální centrum Česká republika a Centrum pro komunitní práci, 2003, s. 28.
}

pro strategické plánování edukační činnosti, musí si nejprve ujasnit, co se pod pojmem strategického plánu muzejní edukace skrývá.

\section{Jak definovat strategické pláno- vání vzdělávací činnosti?}

Strategické řízení a plánování by v ideálním případě mělo provázet všechny oblasti činnosti dané organizace. Mohou však být vypracovány rovněž dílčí strategické plány pro jednotlivá odvětví jako například strategický plán vzdělávací činnosti muzea. Tento konkrétní strategický plán se úzce zaměřuje na výchovně-vzdělávací činnost muzea, tj. muzejní edukaci. Muzejní edukace se zde však musí chápat ve své komplexnosti, kdy vzdělávací činnost muzea zahrnuje nejen edukační programy určené školám i širší veřejnosti, ale i výstavní činnost a práci s veřejností vůbec. Zaměření strategického plánu na muzejní edukaci pak ovlivňuje také způsob zpracování situační analýzy, strategických cílů či implementačního plánu.

Pro účely textu se tedy chápe pojem strategický plán vzdělávací činnosti muzea jako formální dokument (strategický plán) obsahující: plán muzejní edukace na konkrétní časové období obsahující vizi a poslání vzdělávací činnosti, rozbory vnitřního a vnějšího prostředí, definované kritické faktory úspěchu, dlouhodobé i krátkodobé cíle, konkrétní zvolenou strategii pro naplnění těchto cílů a podrobný harmonogram kroků a úkolů v rámci dané strategie a vymezenou evaluaci úspěšnosti strategického plánu.

V současné české muzejněpedagogické obci se však pro strategický plán vzdělávací činnosti muzea využívá rovněž pojmu vzdělávací strategie nebo vzdělávací politika. Diplomové práce zpracované na brněnské muzeologii na téma strategického plánu muzejní edukace používají pojem vzdělávací strategie 
jako synonymum pro samotný strategický plán, ${ }^{10}$ naproti tomu Petra Šobáňová ve své publikaci Muzejní edukace nebo v Základech muzejní pedagogiky přirovnává vzdělávací strategii muzea ke školnímu vzdělávacímu programu. ${ }^{11}$

Vzdělávací strategie muzea tak dle Šobáňové definuje především obsah a cíle edukační činnosti, její „filozofii edukačního působení daného muzea, jakousi vizi, $k$ níž by měla edukační činnost instituce směřovat."12 Absentuje zde konkrétní časové vymezení a vytyčení konkrétních kroků a úkolů. Nejedná se proto o strategický plán jako takový, ale spíše o jakési stanovení poslání a vize muzejní edukace - prohlášení o tom, kam vzdělávací činnost muzea směřuje a jaké prostředky $\mathrm{k}$ naplnění této představy využívá.

Pro takovýto dokument však zahraniční muzejněpedagogická praxe využívá termín vzdělávací politika muzea. Jedná se o „dokument specifikující roli vzdělávání v muzeu, jeho priority a směřování $v$ této oblasti na předem stanovené časové období."13 Na první pohled by se tak mohlo zdát, že se jedná o synonymum pro vzdělávací strategii, nicméně vzdělávací politika definuje dlouhodobý vztah muzea ke vzdělávání a jeho program bez strategických cílů a podrobných kroků $\mathrm{k}$ implementaci. Ve srovnání se strategií tedy vzdělávací politika muzea není plánem, ale spíše jakýmsi prohlášením.

\footnotetext{
10 Např́íklad PAVLÍČKOVÁ, Pavla. Vzdělávací strategie Městského muzea a galerie Polička. Brno: Masarykova univerzita, Filozofická fakulta, Ústav archeologie a muzeologie, 2009. Diplomová práce. Vedoucí práce Mgr. Lenka Mrázová.

11 ŠOBÁŇOVÁ, Petra. Plánování edukačních aktivit muzea. In Základy muzejní pedagogiky. Studijní texty. Brno: Moravské zemské muzeum, Metodické centrum muzejní pedagogiky, 2014, s. 68 .

12 ŠoBÁŇOVÁ, Petra. Muzejní edukace. Olomouc: Univerzita Palackého v Olomouci, Pedagogická fakulta, 2012, s. 118.

13 What is an education policy? [online]. [cit. 2015-02-11]. Dostupný z www: ' http://www.

londonmuseums.org/intro.htm
}

Eilean Hooper-Greenhill uvádí již v publikaci z počátku devadesátých let, že vzdělávací „politika je prohlášení definující charakter poskytovaných služeb..." Zároveň Hooper-Greenhill navrhuje pro rozvoj muzejní edukace vytvořit dokument (strategický plán vzdělávací činnosti) zahrnující poslání edukační činnosti muzea, vzdělávací politiku (záměr a priority), vzdělávací strategii (strategické cíle na dané plánovací období) nebo akční plán (harmonogram činností na plánovací období). ${ }^{15}$ Správě bychom měli rozlišovat tedy tři samostatné termíny.

\section{Strategický plán vzdělávací čin-} nosti muzea je komplexní dokument plánující na konkrétní období edukační činnost, zahrnuje v sobě vzdělávací politiku (poslání, vize, analýza edukační činnosti) a strategii (postup k dosažení cílů). Pojem strategický plán vzdělávací činnosti muzea se s ohledem na stručnost a zjednodušení zúžil na sousloví vzdělávací strategie. Právě pro četné rozšíření tohoto sousloví je tak často teorie strategického plánování muzejní edukace nejasná, nebot' strategií se ve strategickém marketingu rozumí pouze zvolený postup k naplnění stanovených cílů, rozpis jednotlivých strategických operací a kroků. Strategie tvoří tedy nezbytnou součást strategického plánu vzdělávací činnosti muzea (zkráceně vzdělávací strategie). Ten se dále neobejde ani bez vzdělávací politiky.

Vzdělávací politikou rozumíme vymezení směřování a obecných cílů muzejní edukace. Vzdělávací politika může být jednak součástí strategického plánu vzdělávací činnosti, ale stejně tak se může stát

\footnotetext{
14 HOOPER-GREENHILL, Eilean (ed.). Writing a Museum Education Policy. Leicester: Department of Museum Studies, University of Leicester, 1991, s. 8-9.

15 HOOPER-GREENHILL, Eilean (ed.). Writing a Museum Education Policy. Leicester: Department of Museum Studies, University of Leicester, 1991, s. 7-8.
}

samostatným koncepčním dokumentem (bez strategických operací a implementačního plánu). Protože se vyznačuje stručnějším obsahem a nižší náročností na vypracování (bez podrobných analýz), jeví se vzdělávací politika jako vhodný nástroj pro strategické řízení menších regionálních muzeí, jež dosud postrádají zaměstnance vyhrazeného pro edukační činnost muzea.

Jednoznačně definované pojmy na předchozích řádcích a jejich rozlišování napomůže $\mathrm{k}$ lepší orientaci v teorii strategického plánování a usnadní přistoupení ke strategickému plánování vzdělávací činnosti muzea.

\section{Jak postupovat při strategickém plánování?}

I přes proměnlivost prostředí neziskových subjektů, kam řadíme i muzea, je strategické plánování procesem s pevně stanovenými zákonitostmi. Začíná vytvořením strategického plánu, pokračuje realizací včetně jeho případného přizpůsobení nenadálým změnám, uzavírá jej zhodnocení dosažených výsledků nebo nenaplněných cílů a zahájení nového plánovacího procesu. Pro přípravu a realizaci strategie přitom platí pravidla použitelná jak v ziskovém sektoru, tak v muzejní praxi. Přesto není žádný univerzální vzorec, co přesně má strategie obsahovat. „Každá strategie bude vždy jedinečná, protože i jednotlivá muzea jsou jedinečná - s vlastní strukturou návštěvníků, sbírek, aspiracemi, zaměstnanci, dobrovolníky a jinými zdroji. Nicméně existuje několik klíčových bodů, které by měla každá strategie obsahovat v té či oné podobě. “16

Žádná strategie, a to ani ta vzdělávací, jako formální dokument se neobejde bez prvotní analýzy minulého i současného stavu dané

16 What should a policy contain? [online]. [cit. 2015-03-22]. Dostupný z www: ‘ http://www. londonmuseums.org/policy.htm 
muzejní edukace, následného definování poslání, vize a dosažitelných cílů, přičemž musí obsahovat také prostředky a úkoly, jimiž budou cíle naplněny, nebo časový harmonogram s krátkým shrnutím a hodnotícími kritérii v podobě tzv. akčního plánu. Podrobněji rozvádí postup strategického plánování Jiří Bárta, který jej shrnuje do šesti kroků. ${ }^{17}$

\section{Nejprve doporučuje vypracovat} revizi dosavadní historie organizace i tamní edukace a její aktuální situaci se zaměřením na minulé i současné cíle a strategie, finanční situaci, vývoj organizační struktury, programovou nabídku a portfolio klientů, na základě tohoto náhledu pak ověrit funkčnost dosavadního poslání. Následuje situační analýza vnitřního i vnějšího prostředí organizace, která provádí rozbor jejích silných stránek, slabin, příležitostí či hrozeb. Podrobná analýza umožňuje odhalit tzv. kritické faktory úspěchu ovlivňující další rozvoj edukace daného muzea, jež pak dávají základ pro stanovení dlouhodobých cílů organizace. Nezbytné je rovněž rozpracování postupu, jak jednotlivých cílů dosáhnout, a kritéria pro hodnocení jejich naplnění. Poslední krok spočívá v implementačním či akčním plánu vymezujícím způsob zavedení plánovaných změn do každodenní praxe muzejněpedagogické činnosti daného muzea.

Proces strategického plánování má tedy i přes svoji charakteristickou individuálnost ustálené po sobě jdoucí a na sebe navazující fáze. První úkol strategického plánování tkví v definování poslání (někdy též mise), tj. krátce a jasně formulovaném smyslu a cíli vzdělávací činnosti dané instituce, jenž odpovídá na otázky jejího účelu, jedinečnosti, směřování, ale i důvodu samotné existence. Poslání rovněž v ideálním případě reflektuje vztah organi-

\footnotetext{
17 BÁRTA, Jiří. Strategické pánování pro neziskové organizace. Praha: Nadace rozvoje občanské společnosti, 1997, s. 18-19.
}

zace k ostatním konkurentům či její etický kodex a hodnoty. ${ }^{18}$ Jiří Bárta přejímá od Freda Davida pět otázek, na které by poslání mělo odpovídat: Kdo jsou naši klienti? Jaké jsou hlavní produkty organizace? $\mathrm{V}$ jakém regionu a $\mathrm{v}$ jaké oblasti instituce působí? Jaké hodnoty a jakou filozofii organizace uznává? V čem spočívá její konkurenceschopnost? ${ }^{19}$

Poslání vzdělávací činnosti muzea lze tedy např́ílad definovat takto: Vzdělávací činnost muzea zpřístupňuje výstavní činností, edukačními programy a dalšími doprovodnými akcemi hmotné doklady i informace o historii, umění, kultuře a př́rodě. Napomáhá rozvíjet zájem o další poznání, budovat kladný vztah ke kulturním institucím, národní hrdost, kulturní identitu a sounáležitost $\mathrm{s}$ rodným regionem. $\mathrm{K}$ tomuto účelu pomáhá muzeu kvalitní odborné personální obsazení, stejně jako jedinečný sbírkový fond.

Odborná literatura se mírně rozchází v zahrnutí vize organizace do strategického plánu. Jiří Bárta ji zcela vynechává, naproti tomu Ladislav Kesner vyzdvihuje její užitečnost ve vyjádření „toho, čím by organizace měla být, kde by sama sebe chtěla vidět $v$ časovém horizontu strategického plánu. "20 Dagmar Jakubíková pak uvádí tři stěžejní cíle vize - vyjasnění směřování organizace, motivace $\mathrm{k}$ vykročení správným směrem, účinná a rychlejší koordinace úsilí zaměstnanců. ${ }^{21}$ Vize se pro ni jeví stejně nepostradatelná jako poslání. Vizi vnímá jako obraz budoucnosti a poslání jako důvod existence, přičemž rovnou významnost obou části strategie dokládá tvrzením „ř́dit podnik $s$ nejasnou

\footnotetext{
18 JAKUBÍKOVÁ, Dagmar. Strategický marketing. Strategie a trendy. Praha: Grada, 2013, s. 21.

19 BÁRTA, Jiří. Strategické pánování pro neziskové organizace. Praha: Nadace rozvoje občanské společnosti, 1997, s. 30.

20 KESNER, Ladislav. Marketing a management muzeí a památek. Praha: Grada, 2005, s. 276.

21 JAKUBÍKOVÁ, Dagmar. Strategický marketing. Strategie a trendy. Praha: Grada, 2013, s. 20.
}

vizí a posláním je velmi obtížné, často nemožné." ${ }^{22}$

Vizí muzejní edukace pak může být formulace: Vzdělávací činnost tvoři díky kvalitě poskytovaných služeb a vysoké odbornosti všech zaměstnanců součást formálního i celoživotního vzdělávání. Muzeum samotné je partnerem všech stupňů škol a komunitním centrem poskytujícím poznání, poučení i zábavu.

Dalším nezbytným obsahem každé strategie jsou strategické cíle vzdělávací činnosti, které se člení na marketingové, ekonomické, majetkové, rozvojové, personální a ostatní. ${ }^{23}$ Cíle ve všech kategoriích však musí vycházet z principu SMART. Název tohoto pravidla vytvořila počáteční písmena anglických termínů: specific (specifický), measurable (měřitelný), agreed (akceptovatelný), realistic (dosažitelný), trackable (sledovatelný). Porušením některého z těchto principů hrozí, že cíl nebude jasně definován a stane se spíše jakýmsi prohlášením, čímž nelze dostatečně zhodnotit jeho naplnění a proces strategického plánování pozbude závěrečnou fázi evaluace. Jedním ze strategických cílů tak může být např́klad - Zvýšit míru prezentace sbírky muzea nad rámec výstavní činnosti. $\mathrm{Z}$ tohoto dlouhodobého cíle se pak odvíjí i cíl krátkodobý - Rozvíjet možnosti ve zpřístupnění muzejní sbírky formou edukačních programů nezávislých na výstavní činnosti.

Aby však cíle splňovaly výše uvedené zásady, musí je tvưrce strategie stanovit dle výsledků podrobné situační analýzy zaměřené na edukační činnost muzea. Situační analýza umožňuje kromě přesnějšího stanovení strategických cílů se také zorientovat $\mathrm{v}$ aktuálním stavu muzejní edukace dané instituce,

\footnotetext{
22 JAKUBÍKOVÁ, Dagmar. Strategický marketing. Strategie a trendy. Praha: Grada, 2013, s. 24.

23 Tvorba strategie a strategické plánování. Teorie a praxe. Praha: Grada, 2012, s. 89.
} 
rozpoznat vlastní limity i možnosti růstu. Dále také lépe poznat spektrum klientů (návštěvníků) a jejich potřeby nebo prostředí, kde působí (konkurence, legislativa, ekonomika a podobně). Čím pečlivěji a detailněji analýzu tvưrce strategie rozpracuje, tím si vytváří širší a cílenější podklad pro návrh samotné strategie. Komplexní analýza pro účel strategického plánování by tak měla zahrnovat vnitřní revizi organizace včetně prostorové kapacity, výstupů vlastní činnosti či finančních i lidských zdrojů určených pro vzdělávací činnost muzea. Zaměřit se však musí také na prostředí, $v$ němž funguje, a na faktory $z$ něj vycházející a ovlivňující organizaci a její edukaci, stejně jako na cílové skupiny - jejich potřeby, očekávání a přání. ${ }^{24}$

Autoři publikace Museum Marketing and Strategy pak situační analýzu vystihují vhodnějším termínem „environmental scan“25 a rozlišují ji na vnitřní a vnější prostředí, jež se vzájemně ovlivňují. Do vnějšího prostředí řadí příležitosti, hrozby, výzvy v podobě konkurence, prostředí trhu (vzdělávací činnost místní knihovny, střediska volného času atp.). Pod vnitřní prostředí zahrnují silné a slabé stránky, marketingový audit, vnitřní revizi a stakeholders muzea (stát, zřizovatel, zaměstnanci, návštěvníci apod.). ${ }^{26} \mathrm{~V}$ rámci analýzy vnějšího prostředí tak tvůrce vzdělávací strategie sleduje kromě možných konkurentů zejména nejrůznější dokumenty ukotvující muzejní edukaci (koncepce rozvoje muzejnictví, strategické plány zřizovatele atd.) a umožňující její rozvoj (rámcové vzdělávací pro-

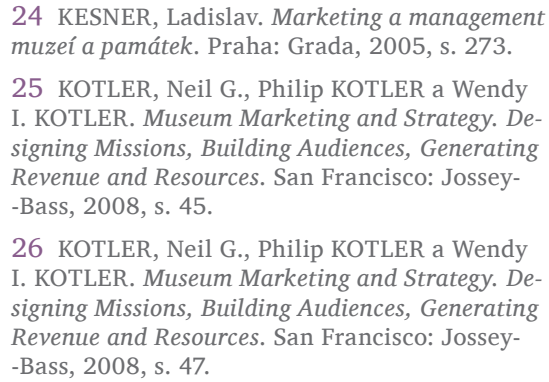

gramy, školní vzdělávací programy místních škol apod.), stejně jako průměrný věk či zaměstnanost v regionu nebo aktuální trendy ve využívání moderních technologií. Analýza vnitřního prostředí obvykle obsahuje stručnou historii vzdělávací činnosti daného muzea, rozbor pracovníků (jejich profilací, zkušeností a možností v oblasti muzejní edukace), budov i sbírky (možnosti využití ke vzdělávací činnosti), zaměření výstavní činnosti a v neposlední řadě také podrobný rozbor edukační činnosti (zaměření, používané metody atp.).

Při tvorbě analýzy pak pomáhá řada marketingových metod. Kupříkladu metoda 4C shrnuje ve čtyřech slovech vše výše uvedené - customer (zákazník), country (specifické aspekty daného státu), cost (náklady), competitors (konkurence). Pro analýzu vnějšího prostředí (makroprostředí) může tvůrce strategického plánu použít tzv. PEST analýzu založenou na čtyřech faktorech: politicko-právní, ekonomický, sociokulturní a technologický. ${ }^{27} \mathrm{~K}$ analýze vnitřního prostředí dopomůže metoda VRIO zaměřená na vlastní zdroje organizace, které dělí na fyzické (prostory, vybavení atd.), lidské (atmosféra, hodnotová orientace, struktura zaměstnanců atd.), finanční nebo nehmotné (image instituce). Tyto zdroje, jimiž muzeum disponuje, pak Dagmar Jakubíková posuzuje podle toho, jestli mají obecný přínos, jsou jedinečné a nenapodobitelné, ale rovněž zda je organizace schopná těchto zdrojů využívat. ${ }^{28}$

V neposlední řadě doporučovanou a hojně využívanou metodou je také SWOT analýza, nebot' se jedná o „nejjednodušši systematický přistup pro analýzy společnosti a konkuren-

\footnotetext{
27 JAKUBÍKOVÁ, Dagmar. Strategický marketing Strategie a trendy. Praha: Grada, 2013, s. 83.

28 JAKUBÍKOVÁ, Dagmar. Strategický marketing. Strategie a trendy. Praha: Grada, 2013, s. 88.
}

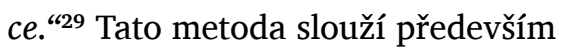
jako užitečný nástroj sumarizace výsledků podrobné situační analýzy a její cíl spočívá v určení míry schopnosti muzea flexibilně se vyrovnat se změnami v prostředí. ${ }^{30}$ SWOT analýza přehledně shrnuje a zdůrazňuje zásadní zjištění podrobné situační analýzy - podtrhuje silné a slabé stránky (strengths, weaknesses), př́ležitosti (opportunities) či hrozby (threats).

Dagmar Jakubíková doporučuje začít SWOT analýzu rozborem vnějšího prostředí skrze vymezení příležitostí a hrozeb. V této části se tvůrce musí zaměřit nejen na vzdálenější makroprostředí muzejní edukace, tj. politicko-právní oblast (rámcové vzdělávací programy, koncepce rozvoje a strategické plány zřizovateli̊ a škol atp.), ekonomika (vypisované granty a dotace atd.), sociálně-kulturní vlivy a další, ale rovněž také na snáze ovlivnitelnější, bližší mikroprostředí (návštěvníci, potenciální návštěvníci, pravidelné školní skupiny atp.).

Správně zpracovaná analýza příležitostí odpovídá na otázky: Jaké nové edukační programy a akce můžeme nabídnout? Jaké nové schopnosti a dovednosti můžeme získat? Jak se můžeme stát jedinečnými? Pro jaké nové typy návštěvníků můžeme sloužit? Jakých změn na trhu můžeme využít? Jaké nové myšlenky, metody, techniky a technologie můžeme použít? ${ }^{31}$ Při zjištování možných hrozeb hledáme odpovědi na otázky: Jaké nové myšlenky, metody, techniky a technologie nás mohou oslabit? Která konkurence nás může ohrozit? Existují pro nás nějaké právní, ekonomické nebo politické hrozby? Mění se potřeby na-

\footnotetext{
29 Tvorba strategie a strategické plánování. Teorie a praxe. Praha: Grada, 2012, s. 303.

30 JAKUBÍKOVÁ, Dagmar. Strategický marketing. Strategie a trendy. Praha: Grada, 2013, s. 103. 31 KOTLER, Neil G., Philip KOTLER a Wendy I. KOTLER. Museum Marketing and Strategy. Designing Missions, Building Audiences, Generating Revenue and Resources. San Francisco: Jossey-Bass, 2008, s. 48.
} 
šich návštěvníkư? Jaké další změny $\mathrm{v}$ oblasti trhu nás mohou negativně ohrozit? ${ }^{32}$ Př́ležitostí muzea tedy může kupř́íkladu být modernizace výstavního fundu a reflektování aktuálních trendů muzejního výstavnictví k vyšší atraktivitě expozic i výstav, což reaguje na hrozbu nedostatečné atraktivnosti tradičních muzejních výstav a expozic.

Vnitřní prostředí muzea lze nejlépe analyzovat prostřednictvím definování silných a slabých stránek instituce. Silné stránky hledají odpovědi na otázky: Co $\mathrm{k}$ nám přivádí návštěvníky? Co je přiměje doporučit nás? Jaké schopnosti máme a $\mathrm{v}$ jakých vynikáme? Co můžeme dělat jen my a nikdo jiný? Jakých úspěchů jsme nedávno dosáhli a proč? ${ }^{33}$ Slabiny organizace odhalují otázky: Jaké schopnosti nám chybí a v čem nejsme dobří? Co ostatní dělají lépe než my? S jakými nezdary jsme se nedávno potýkali a proč? Proč si lidé vybírají naše konkurenty? Proč nás dříve spokojení návštěvníci opouštějíi? ${ }^{34}$ Silná stránka bezesporu každého muzea spočívá v unikátním neustále se rozšiřujícím sbírkovém fondu, avšak mezi slabé stránky lze zároveň zařadit omezené možnosti v prezentaci sbírky (omezené výstavní plochy).

Odpovědi na výše uvedené otázky a vypracování SWOT analýzy napomůže stanovit nejen strategické cíle, ale především také tzv. kritické faktory úspěchu, čili faktory významně ovlivňující další rozvoj

\footnotetext{
32 KOTLER, Neil G., Philip KOTLER a Wendy I. KOTLER. Museum Marketing and Strategy. Designing Missions, Building Audiences, Generating Revenue and Resources. San Francisco: Jossey-Bass, 2008, s. 48

33 KOTLER, Neil G., Philip KOTLER a Wendy I. KOTLER. Museum Marketing and Strategy. Designing Missions, Building Audiences, Generating Revenue and Resources. San Francisco: Jossey-Bass, 2008, s. 48.

34 KOTLER, Neil G., Philip KOTLER a Wendy I. KOTLER. Museum Marketing and Strategy. Designing Missions, Building Audiences, Generating Revenue and Resources. San Francisco: Jossey-Bass, 2008, s. 48.
}

edukace konkrétního muzea. ${ }^{35} \mathrm{Ne}$ jenže kritické faktory úspěchu musí vyplynout z podrobné situační analýzy, ale rovněž musí trvale reflektovat měnící se podmínky trhu a vnějšího prostředí vůbec. Kritické faktory úspěchu představují aktivity, jimiž daná muzejní edukace vyniká a jimiž je schopna překonat konkurenci a na nichž může založit svůj úspěšný rozvoj a dlouhodobou konkurenční výhodu, např́íklad plně využívat potenciál vlastní muzejní sbírky a dále jej zhodnocovat. ${ }^{36} \mathrm{~K}$ dosažení stanovených strategických cílů dále kritické faktory úspěchu ovlivňují výběr vhodných strategických operací (kroků), respektive celé strategie.

\section{Strategické operace představují} činnosti či akce vedoucí $k$ naplnění vytyčených cílů a uvádějí strategický plán vzdělávací činnosti do života. ${ }^{37}$ Společně pak tvoří jednotnou strategii, která vychází ze situační analýzy, proto „dobrá strategie využivá vnějšich př́ležitostí, omezuje nebo se vyhýbá vnějším hrozbám, staví na silných stránkách organizace a posiluje její slabé stránky. “38 Proces stanovení strategických operací a tím i celkové strategie prochází třemi fázemi. Nejprve je nezbytné zvážit různé strategické operace pro naplnění stanoveného cíle, dále tyto strategické operace kriticky vyhodnotit a vybrat potenciálně nejúčinnější. ${ }^{39}$

\section{Podle autorů publikace Museum Marketing and Strategy sestává} strategická operace z pěti položek: identifikace jednoho nebo více cílo-

\footnotetext{
35 BÁRTA, Jiří. Strategické pánování pro neziskové organizace. Praha: Nadace rozvoje občanské společnosti, 1997, s. 44.

36 Tvorba strategie a strategické plánování. Teorie a praxe. Praha: Grada, 2012, s. 110.

37 Tvorba strategie a strategické plánování. Teorie a praxe. Praha: Grada, 2012, s. 92.

38 BÁRTA, Jiří. Strategické pánování pro neziskové organizace. Praha: Nadace rozvoje občanské společnosti, 1997, s. 53.

39 BÁRTA, Jiří. Strategické pánování pro neziskové organizace. Praha: Nadace rozvoje občanské společnosti, 1997, s. 61.
}

vých trhů a jejich priorit, nalezení jasně definované konkurenční pozice pro jednotlivý cílový trh, formulace marketingového mixu reflektující potřeby cílových trhů, vytvoření strategie diferencující pozici muzea, usnesení o programech s portfoliem produktů. ${ }^{40}$ Jiří Bárta pak předkládá dle Heinze Weihricha čtyři základní nástroje vymezení strategických operací vycházející ze SWOT analýzy. ${ }^{41}$ První a Bártou doporučovanou metodou je SO strategie založená na vyzdvižení silných stránek a využití př́iležitostí z vnějšího prostř̌edí. K využívání příležitostí vybízí také WO strategie, která rovněž pracuje na zlepšení slabých stránek. Zaměřením na silné stránky a současným potlačením hrozeb se vyznačuje strategie ST. Spíše jako obranná se jeví strategie WT minimalizující slabé stránky a vyhýbající se hrozbám vnějšího prostředí.

Ani vhodně zvolenou strategií $\mathrm{k}$ naplnění strategických cílů však proces strategického plánování nekončí. Jeho důležitou částí, která převádí formální dokument strategického plánu do běžného dne vzdělávací činnosti muzea, je nepostradatelný implementační (akční) plán. V průběhu implementace strategického plánu se vypracovávají a realizují jednotlivé plány postupu, rozdělují se zdroje, produkují se různé směrnice a pokyny $\mathrm{k}$ zefektivnění činnosti a vzájemné komunikace tak, aby byly plněny úkoly vyplývající ze strategického dokumentu. ${ }^{42}$ Dle Jiřího Bárty pak implementační plán obsahuje například krátkodobé dílčí cíle pro jednotlivé služby či projekty, plán služeb, projektů a programů na stanovené období, personální plán, finanční plán či

\footnotetext{
40 KOTLER, Neil G., Philip KOTLER a Wendy I. KOTLER. Museum Marketing and Strategy. Designing Missions, Building Audiences, Generating Revenue and Resources. San Francisco: Jossey-Bass, 2008, s. 93.

41 BÁRTA, Jiří. Strategické pánování pro neziskové organizace. Praha: Nadace rozvoje občanské společnosti, 1997, s. 53-54.

42 Tvorba strategie a strategické plánování. Teorie a praxe. Praha: Grada, 2012, s. 28.
} 
stanovení odpovědných pracovníků a termínů plnění. ${ }^{43}$

Zejména stanovení krátkodobých cílů se jeví jako velmi důležitá část při vypracování implementačního plánu, protože se jedná o drobné úkoly převáděné do pracovního procesu od samého počátku aplikace strategického plánu. Dobře zpracovaný implementační plán ve výsledku obrazně představuje jakousi knihu receptů na přenesení formulovaného strategického plánu do praxe, stejně jako vodítko pro průběžné i konečné hodnocení strategie.

Evaluace strategického plánu zahrnuje veškeré aktivity směřující ke zjištění poměru stavu mezi výsledky plánovanými a reálně dosaženými. Kromě zhodnocení výsledků v závěru období strategického plánu však musí $\mathrm{k}$ evaluaci docházet již $\mathrm{v}$ průběhu realizace vzdělávací strategie tak, aby probíhající procesy reagovaly na proměny vnějšího prostředí. Dagmar Jakubíková pak přidává ještě kontrolu preventivní, jež vyhodnocuje množstevní i kvalitativní odchylky a usměrňuje celý proces ke zvýšení příznivého srovnání reálných výsledků s plánovanými. Ladislav Kesner však správně postř̌ehl, že muzea poskytují společnosti obtížně hodnotitelné služby a často zde také chybí snaha po evaluaci vlastní činnosti. Oprávněně však připomíná, že chce-li muzeum dosáhnout potřebných prostředků z finančních zdrojů, musí být schopno srozumitelně doložit přínos vlastní činnosti pro společnost. ${ }^{44}$

Každá z výše uvedených fází vypracování vzdělávací strategie si vyžaduje náležité zpracování, a tomu i odpovídající čas nad tím strávený. Tento postup je provázaný, pevně daný a vynechá-li se jedna

43 BÁRTA, Jiří. Strategické pánování pro neziskové organizace. Praha: Nadace rozvoje občanské společnosti, 1997, s. 64.

44 KESNER, Ladislav. Marketing a management muzeí a památek. Praha: Grada, 2005, s. 279-280. fáze, není odkud čerpat pro fázi navazující. Avšak čas strávený nad strategickým plánováním a poctivě vypracovaná vzdělávací strategie se zúročí rozvojem edukační činnosti daného muzea nebo ulehčením při každodenní práci. Pokud se tedy dané muzeum či odpovědný pracovník rozhodne, že prínos strategického plánu vzdělávací činnosti muzea převyšuje náročnost procesu jeho vypracování, je dobré připravit se na rizika ohrožující implementaci plánu, na která lze v průběhu plánovacího procesu narazit.

\section{Jak se vyhnout rizikům ohrožují- cím převedení plánu do praxe?}

Kvalita strategického plánu se sice odvíjí od tří faktorů - kompetentnost tvůrce, množství investované energie, forma řízení, ${ }^{45}$ avšak nedostatky ohrožující převedení plánu $\mathrm{v}$ realitu mohou nastat nezávisle na těchto třech faktorech v samotném počátku strategického plánování, tj. $v$ jeho přípravě, bez ohledu na ony tři faktory. Aby již př́iprava neohrozila realizaci plánu, navrhuje Ladislav Kesner "formální řád a rámec," "46 jímž by se proces přípravy měl řídit. Nejprve musí odpovědný pracovník vybrat konkrétní osoby podílející se na tvorbě plánu (alespoň tř̌i lidé), určit časový harmonogram, připravit kompletní potřebné podklady, rozdělit dílčí realizace mezi jednotlivé spolupracovníky. ${ }^{47}$ Pokud návrh na vypracování (nejen) vzdělávací strategie nevzejde přímo $\mathrm{z}$ vedení muzea, musí se nejprve navrhující řadový zaměstnanec (zejména muzejní pedagog) ujistit o podpoře strategického plánu managementem, protože role vedení muzea zůstává, přestože zpracování

\footnotetext{
45 KAŽMIERSKI, Tomáš a Petr PELCL. Projektové a strategické plánování pro neziskové organizace. Praha: Regionální environmentální centrum Česká republika a Centrum pro komunitní práci, 2003, s. 33.

46 KESNER, Ladislav. Marketing a management muzeí a památek. Praha: Grada, 2005, s. 279.

47 KESNER, Ladislav. Marketing a management muzeí a památek. Praha: Grada, 2005, s. 279.
}

plánu nenavrhlo, logicky klíčová. ${ }^{48}$ Strategický plán ale nemusí být bezpodmínečně oficiálně přijatým a schváleným muzejním dokumentem, může se stát také ideálním prostředkem pro rozvíjení práce muzejního pedagoga, jen tomu musí být přizpůsobeny adekvátní cíle. Informováni dále musí být nejen nadřízení, ale i kolegové.

Obvykle je sice vždy vhodnější, pokud strategii kompletuje pouze jedna osoba, nicméně strategický plán musí být ve všech bodech prokonzultován s co největším počtem zainteresovaných osob, jež mají nějaký zájem na budoucnosti muzea (zaměstnanci, klíčoví stakeholders atd.). ${ }^{49}$ Nejenže mohou obohatit plán o nové myšlenky či směry, ale také jejich podílení se na přípravě plánu podporuje vlastní zaujetí pro jeho plnění.

Hned ve fázi příprav musí být vymezeno také časové období platnosti vzdělávací strategie. Strategické plány charakterizuje právě jejich dlouhodobost - v muzejních institucích obvykle na dobu tři až pět let. Při stanovení př́liš̌ dlouhého časového rozptylu hrozí marnost značné části stanovených cílů a plánu samotného vlivem proměnlivosti vnějších i vnitřních podmínek fungování organizace. Časové období by mělo vycházet rovněž z charakteru strategického plánu - u vzdělávací strategie se jeví jako praktické řešení nedržet se běžného kalendářního roku, ale odvíjet plán od roku školního. Harmonogramem školního roku se řídí nejen návštěvníci z řad školních skupin, ale i početná kategorie rodin s dětmi stejně jako většina ostatních návštěvníků. Měsíce hlavních letních prázdnin pak zároveň poskytují užitečný volnější

\footnotetext{
48 How to develop your policy [online]. [cit. 2015 03-22]. Dostupný z www: ‘http://www.londonmuseums.org/development.htm

49 How to develop your policy [online]. [cit. 2015 03-22]. Dostupný z www: ‘http://www.londonmuseums.org/development.htm
} 
prostor pro přípravu, revizi i závěrečné hodnocení plánu.

Dále pro úspěch strategického plánování mu musí odpovědný pracovník věnovat dostatek potřebného času a po tuto dobu by mělo být strategické plánování jeho prioritou. Značnou časovou náročností se vyznačuje klíčová součást plánovacího procesu tvořená výše zmiňovanými konzultacemi s širokým okruhem spolupracujících a nezbytné analýzy.

Strategický plán totiž musí reflektovat potřeby všech stakeholders - od zrrizovatele až $\mathrm{k}$ samotné veřejnosti. ${ }^{50}$ Správný plán dále vychází z výsledků podrobné situační analýzy, aby využil př́ležitostí, omezil dopad vnějších hrozeb, byl založen na silných stránkách a transformoval slabé stránky na silné. ${ }^{51}$ Při zpracovávání funkční vzdělávací strategie se jen stěží autor obejde také bez výzkumu vzdělávacích potřeb cílových skupin. Chybějící výzkum tohoto druhu zaprríčiňuje nejistotu při stanovení jednotlivých cílů a záměrů, proto se snadno může stát, že stanovené cíle se minou s potřebami a zájmem. ${ }^{52}$

Ač se strategické plánování vyznačuje výhledem na delší časový úsek, nelze podcenit ani cíle krátkodobé, protože pouze plněním menších cílů se dosáhne cílů dlouhodobých. Nejprve musí tvůrce strategie zvážit stávající strukturu činností, z níž odvodí krátkodobé cíle a jejich množství. Při stanovení cílů krátkodobých se tedy neobejde bez revize dosavadních služeb či programů, kdy se musí rozhodnout, zdali tyto již existující činnosti zachová, roz-

\footnotetext{
50 KESNER, Ladislav. Marketing a management muzeí a památek. Praha: Grada, 2005, s. 279. 51 BÁRTA, Jiří. Strategické pánování pro neziskové organizace. Praha: Nadace rozvoje občanské společnosti, 1997, s. 53.

52 How to develop your policy [online]. [cit. 2015 03-22]. Dostupný z www: ' http://www.londonmuseums.org/development.htm
}

šîríí nebo zruší. ${ }^{53}$ Úspěšné aplikace strategického plánu do praxe se docílí jedině okamžitou snahou o plnění krátkodobých cílů od počátku implementace. ${ }^{54}$ Smysl a kritérium úspěšnosti procesu plánování tkví tedy nikoliv v plánu samotném, ale $\mathrm{v}$ jeho schopnosti převádět $\mathrm{v}$ něm stanovené cíle a záměry do každodenní činnosti organizace, ${ }^{55} \mathrm{k}$ čemuž slouží tzv. implementační (akční) plán, bez kterého zůstává plán bezvýznamným dokumentem.

Při sestavování implementačního plánu musíme neustále kontrolovat jeho dosažitelnost, tedy že je v silách muzea (personálních i finančních) splnění strategického plánu ve stanoveném časovém horizontu. Předimenzovaný akční plán nemůže být ani prres sebevětší snahu realizován. Proto jeho autor musí v něm obsažené cíle a postupy optimalizovat $s$ ohledem na reálné možnosti instituce, a tak se zde opět objevuje podmínka konzultace se spolupracovníky, zde zejména s kolegy, jichž se plnění plánu prímo dotýká. ${ }^{56}$ Významnost správně zpracovaného implementačního plánu založeného na reálných základech vedoucí $\mathrm{k}$ dosažení cílů podtrhuje teze Jiřího Bárty, že „teprve změněná realita je měřítkem úspěchu strategického plánování a ř́izení."57

Kromě možných rizik v př́ípravné fázi strategického plánu vzdělávací činnosti muzea musíme zodpovědně zvažovat formální podobu konečného dokumentu. Kromě jednoduchosti, přehlednosti a stručnosti nesmí-

\footnotetext{
53 BÁRTA, Jiří. Strategické pánování pro neziskové organizace. Praha: Nadace rozvoje občanské společnosti, 1997, s. 68.

54 BÁRTA, Jiří. Strategické pánování pro neziskové organizace. Praha: Nadace rozvoje občanské společnosti, 1997, s. 66.

55 BÁRTA, Jiří. Strategické pánování pro nezis kové organizace. Praha: Nadace rozvoje občanské společnosti, 1997, s. 66.

56 How to develop your policy [online]. [cit. 2015 03-22]. Dostupný z www: <http://www.londonmuseums.org/development.htm

57 BÁRTA, Jiří. Strategické pánování pro nezis kové organizace. Praha: Nadace rozvoje občanské společnosti, 1997, s. 19.
}

me podcenit ani grafickou úpravu dokumentu (zvýraznění nadpisů, typ písma, využití piktogramů, doplnění o ilustrační obrázky atp.).

Ani vyhotovením formálního dokumentu vzdělávací strategie, kdy jsme se úspěšně vyhnuli všem výše zmíněným rizikům, však možné ohrožení procesu strategického plánování a řízení nekončí. Strategický plán musí být ve své formální podobě schválen vedením organizace, a poté poskytnut všem, jejichž práci plán ovlivňuje, stejně jako těm, jež o něj mohou mít $\mathrm{z}$ nejrůznějších důvodů zájem (poskytovatelé dotací, veřejnost atd.). Aby implementace strategického plánu proběhla úspěšně, doporučuje se uspořádat pro management organizace a klíčové zaměstnance poradu, kde budou podrobně rozebrány jednotlivé body plánu a kde se autor vzdělávací strategie ujistí, že všichni zainteresovaní chápou svoji roli v aplikaci strategického plánu do praxe. ${ }^{58}$

$\mathrm{V}$ neposlední řadě musíme průběžně „monitorovat prriměřenost a úspěšnost vzdělávací strategie a přizpůsobovat ji dle potřeby - o př́padných změnách informovat v̌sechny zúčastněné strany. Vzdělávací strategie je pracovním dokumentem a musí být schopna reagovat na nepředvídatelné změny okolností." ${ }^{59}$ Samozřejmostí by se také měla stát každoroční revize strategického plánu a vyhodnocení výsledků za uplynulý rok. O zjištěném úspěšném plnění, stejně jako o možných problémech a nedostatcích musí být pravidelně informováni všichni, jichž se to týká.

Rizika implementace strategického plánu vycházejí také z obecných negativ strategického plánování, které Jiří Bárta spatřuje např́íklad ve finanční náročnosti. Organizace

\footnotetext{
58 How to develop your policy [online]. [cit. 2015 03-22]. Dostupný z www: ‘http://www.londonmuseums.org/development.htm

59 How to develop your policy [online]. [cit. 201503-22]. Dostupný z www: ' http://www.londonmuseums.org/development.htm
} 
tak ještě před zahájením tohoto procesu musí zvážit své časové i finanční možnosti pro strategické plánování, zdali v aktuální situaci není vhodnější investovat tyto zdroje do důležitějších problémů. ${ }^{60}$ Převedení strategického plánu do praxe může rovněž ohrozit silná vůdčí osobnost s jasnou vizí spoléhající se především na vlastní intuici, nebo momentální krize v organizaci. $\mathrm{V}$ případě krize doporučuje Bárta počkat na zahájení strategického plánování až po vyřešení nejpalčivějších problémů, nebot přínosy strategického plánu se neprojevují v krátkém časovém horizontu tak, aby zažehnaly momentální krizi. ${ }^{61}$ Další výrazné riziko vyplývá z nejistoty implementace strategického plánu - „jestliže od začátku existují pochybnosti o tom, že strategický plán bude implementován, je nutné dobře zvážit, zda věnovat čas, energii a peníze na plánování.“62

Vypracování strategického plánu vzdělávací činnosti muzea je náročným procesem. Vyvarujeme-li se ale možných rizik a podaří-li se vytvořit skutečně funkční vzdělávací strategii, získáme časovou úsporu nad administrativní zátěží (např́íklad při psaní ročního plánu činnosti, žádosti o granty a dotace), lepší představu o významnosti muzejní edukace mezi kolegy a vyhneme se případné stagnaci díky neustálému rozvoji činnosti dle vzdělávací strategie. Každý tvůrce strategie si však musí nutně uvědomit, že složitá realita a rychle se vyvíjející a měnící společnost, ekonomika i politika zvláště pro kulturní organizace vytváří poměrně nestabilní základ, a proto je téměř nemožné plnit dlouhodobější plán beze změny tak, jak byl původně napsán. $\mathrm{Z}$ toho

60 BÁRTA, Jiří. Strategické pánování pro nezis kové organizace. Praha: Nadace rozvoje občanské společnosti, 1997, s. 21.

61 BÁRTA, Jiří. Strategické pánování pro neziskové organizace. Praha: Nadace rozvoje občanské společnosti, 1997, s. 22.

62 BÁRTA, Jiří. Strategické pánování pro nezis kové organizace. Praha: Nadace rozvoje občanské společnosti, 1997, s. 22. důvodu tedy „účelem není mít plán, účelem je vědět, co chci udělat, proč to chci udělat a potom to také udělat; a to všechno navíc postupně podřizovat měnící se realitě života." ${ }^{\text {"63 }}$

\section{POUŽITÁ LITERATURA}

BÁRTA, Jiří. Strategické pánování pro neziskové organizace. 1. vyd. Praha: Nadace rozvoje občanské společnosti, 1997. 126 s. NROS edice. ISBN 80-902302-0-2.

HOOPER-GREENHILL, Eilean (ed.). Writing a Museum Education Policy. Leicester: Department of Museum Studies, University of Leicester, 1991. $32 \mathrm{~s}$.

How to develop your policy [online]. [cit. 2015-03-22]. Dostupný z www: ‘ http:// www.londonmuseums.org/development. htm ${ }^{>}$.

JAKUBÍKOVÁ, Dagmar. Strategický marketing. Strategie a trendy. 2. vyd. Praha: Grada, 2013. 362 s. ISBN 978-80-247-4670-8.

JOHNOVÁ, Radka. Marketing kulturního dědictví a umění. Art marketing v praxi. 1. vyd. Praha: Grada, 2008. 284 s. ISBN 978-80-247-2724-0.

KAŽMIERSKI, Tomáš a Petr PELCL. Projektové a strategické plánování pro neziskové organizace. Praha: Regionální environmentální centrum Česká republika a Centrum pro komunitní práci, 2003. $57 \mathrm{~s}$. ISBN 80-902368-9-8.

KESNER, Ladislav. Marketing a management muzeí a památek. Praha: Grada, 2005. 304 s. ISBN 80-247-1104-4.

KOTLER, Neil G., Philip KOTLER a Wendy I. KOTLER. Museum Marketing and Strategy. Designing Missions, Building Audiences, Generating Revenue and Resources. 2. vyd. San Francisco: Jossey-Bass, 2008. 509 s. ISBN 978-0-7879-9691-8.

MAŽÁROVÁ, Monika. Vzdělávací strategie Jihomoravského muzea ve Znojmě. Brno: Masarykova univerzita, Filozofická fakulta, Ústav archeologie a muzeologie, 2015. Diplomová práce. Vedoucí práce Mgr. Lenka Mrázová.

PAVLÍČKOVÁ, Pavla. Vzdělávací strategie Městského muzea a galerie Polička. Brno: Masarykova univerzita, Filozofická fakulta, Ústav archeologie a muzeologie, 2009. Diplomová práce. Vedoucí práce Mgr. Lenka Mrázová.

ŠOBÁŇOVÁ, Petra. Muzejní edukace. Olomouc: Univerzita Palackého v Olomouci,

63 BÁRTA, Jiří. Strategické pánování pro neziskové organizace. Praha: Nadace rozvoje občanské společnosti, 1997, s. 31
Pedagogická fakulta, 2012. 140 s. ISBN 978-80-244-3003-4.

Tvorba strategie a strategické plánování. Teorie a praxe. 1. vyd. Praha: Grada, 2012. 381 s. ISBN 978-80-247-3985-4.

What is an education policy? [online]. [cit. 2015-02-11]. Dostupný z www: ${ }^{<}$http:// www.londonmuseums.org/intro.htm'.

What should a policy contain? [online]. [cit. 2015-03-22]. Dostupný z www: ‘http:// www.londonmuseums.org/policy.htm?.

Základy muzejní pedagogiky. Studijní texty. Brno: Moravské zemské muzeum, Metodické centrum muzejní pedagogiky, 2014. 103 s. ISBN 978-80-7028-441-4.

\section{MONIKA MAŽÁROVÁ}

Jihomoravské muzeum ve Znojmě, Česká republika

edukace@muzeumznojmo.cz

Po střední pedagogické škole vystudovala dějiny umění na Univerzitě Palackého v Olomouci a muzeologii na Masarykově univerzitě. Od roku 2012 působí v Jihomoravském muzeu ve Znojmě jako muzejní pedagog.

After completing her studies at the Secondary Pedagogical School, she studied History of Art at the Palacký University in Olomouc and Museology at the Masaryk University in Brno. Since 2012 she has been working in the South Moravian Museum in Znojmo as a museum pedagogue. 